\title{
KARAKTERISASI PLASMA LUCUTAN PIJAR KORONA POSITIF PADA KONDISI ATMOSFER DENGAN KONFIGURASI ELEKTRODA TITIK BIDANG DAN PENGARUHNYA TERHADAP KAIN SUTRA ALAM (BOMBYX MORI)
}

\author{
CHARACTERIZATION OF POSITIVE CORONA GLOW DISCHARGE PLASMA \\ IN ATMOSPHERIC CONDITION WITH MULTIPLE POINTS TO PLANE \\ ELECTRODE CONFIGURATION AND ITS EFFECTS TO NATURAL SILK \\ FABRIC (BOMBYX MORI)
}

\author{
Mahendra Kusuma Nugraha, Zaenul Muhlisin, Pandji Triadyaksa \\ Departemen Fisika, Fakultas Sains dan Matematika, Universitas Diponegoro, Semarang \\ E-mail: mahendrakusuma96@gmail.com
}

Tanggal diterima: 15 Maret 2019, direvisi: 4 Juli 2019, disetujui terbit: 12 Juli 2019

\begin{abstract}
ABSTRAK
Eksperimen pembangkitan plasma lucutan pijar korona telah dilakukan dengan menggunakan konfigurasi elektroda titik dan bidang. Kondisi plasma lucutan pijar korona terbentuk secara optimal pada jarak antar elektroda (d) setinggi $2,1 \mathrm{~cm}$ dan $2,4 \mathrm{~cm}$ dan arus saturasi $\left(I_{s}\right)$ terukur sebesar $0,75 \mathrm{~mA}$ dan $1,0 \mathrm{~mA}$. Kondisi tersebut digunakan sebagai dua karakteristik lucutan yang digunakan dalam tahap perlakuan sampel kain sutra alam (Bombyx mori). Pengujian sifat mekanis pada sampel kain sutra alam dengan perlakuan plasma menunjukkan nilai ketahanan jebol yang menurun dibandingkan nilai ketahanan jebol pada sampel kain sutra alam tanpa perlakuan. Pengujian kekuatan serap zat cair (akuades) pada sampel kain sutra alam dengan perlakuan plasma menunjukkan nilai rerata waktu serap $(\tau)$ yang lebih singkat dibandingkan nilai $\tau$ pada sampel kain sutra tanpa perlakuan. Pada kedua tahap tersebut, pengoptimalan maksimum dari nilai ketahanan jebol dan daya serap zat cair (akuades) dicapai pada jarak antar elektroda $(d)$ setinggi $2,1 \mathrm{~cm}$, arus saturasi $\left(I_{s}\right)$ sebesar $0,75 \mathrm{~mA}$ dan waktu perlakuan selama 30 menit. Pengujian sifat mikroskopik membuktikan bahwa dengan adanya perubahan struktur permukaan pada sampel cukup berpengaruh terhadap nilai ketahanan jebol dan rerata waktu penyerapan zat cair (akuades) yang dimiliki. Hasil pengujian pada tahap ini juga menyatakan bahwa tidak ada penambahan jenis baru dari gugus fungsi terkandung pada sampel kain sutra alam yang diberi perlakuan plasma.
\end{abstract}

Kata kunci: plasma lucutan pijar korona positif, kain sutra alam, nilai ketahanan jebol, daya serap zat cair, sifat mikroskopik

\begin{abstract}
Experiments on the generation of corona glow discharge plasma have been carried out using the multiple points to plane electrode configuration. The condition of the corona glow discharge plasma was formed optimally at 2.1 $\mathrm{cm}$ and $2.4 \mathrm{~cm}$ distances between electrodes $(d)$ and with the saturation current $\left(I_{s}\right)$ of $0.75 \mathrm{~mA}$ and $1.0 \mathrm{~mA}$. These conditions were used as two treatment discharge characteristics on samples of natural silk fabric (Bombyx mori). Mechanical property test on the treated sample of natural silk fabric showed that the fiber breakdown resistance value was decreased than the fiber breakdown resistance value in the untreated sample of natural silk fabric. Liquid absorbency strength test on the treated sample of natural silk fabric showed that the absorption time average value ( $\tau)$ took less time than the $\tau$ value in the untreated sample of natural silk fabric. At both stages, the maximum optimization of the breakdown resistance value and liquid absorbency strength was achieved at $2.1 \mathrm{~cm}$ distance between electrodes $(d)$ with the saturation current $\left(I_{s}\right)$ of $0.75 \mathrm{~mA}$ and the treatment time of 30 minutes. Microscopic properties test proved that the change in surface structure on the treated sample had sufficient influence on the breakdown resistance value and the liquid absorption time average value $(\tau)$. The test results at this stage also stated that there was no addition of new types of functional groups contained in the treated sample of natural silk fabric.
\end{abstract}

Keywords: positive corona glow discharge plasma, natural silk fabric, breakdown resistance value, liquid absorbency strength, microscopic properties 


\section{PENDAHULUAN}

Kain sutra telah dikenal sebagai produk tekstil yang terkenal di seluruh dunia atas keunikan dan estetika yang dimiliki. Industri pertanian kain sutra telah menjadi salah satu industri rumahan yang paling penting di sejumlah negara seperti Cina, Jepang, India, Korea, Rusia, Italia dan Perancis. Saat ini, Cina dan India adalah dua produsen utama, bersama-sama memproduksi lebih dari enam puluh persen $(60 \%)$ produksi total dunia setiap tahunnya. ${ }^{1}$ Dalam skala perdagangan produk sutra di Indonesia, permintaan (demand) pasar terhadap produk hasil pertanian sutra (serikultur) khususnya kain sutra cenderung meningkat, dengan rerata peningkatan permintaan per tahun sebesar sepuluh koma lima persen $(10,5 \%){ }^{2}$ Produksi benang sutera di provinsi Sulawesi Selatan masih merupakan yang terbesar di Indonesia dengan angka 54,3 ton atau sekitar 84,8 persen $(\%)$ dari 64,02 ton produksi benang sutra nasional ${ }^{3}$

Fakta mengenai kemajuan dan perkembangan industri tekstil sutra alam di dunia maupun di Indonesia yang dapat dirasakan secara nyata menjadi salah satu alasan utama mengapa inovasi dan riset mempunyai peran penting untuk menopang bahkan mempertajam progresivitas dari industri produk kain sutra terutama dalam segi peningkatan mutu/ kualitas bahan melalui apa yang dikenal dengan istilah penyempurnaan tekstil (textile finishing).

Teknik pencelupan ini termasuk ke dalam salah satu tahap penyempurnaan tekstil yang bertujuan untuk meningkatkan nilai guna dan nilai ekonomi suatu produk tekstil. Akan tetapi, kekurangan dari metode penyempurnaan tekstil dengan teknik pencelupan ini salah satunya adalah limbah hasil proses pencelupan yang kerap menjadi polutan terhadap lingkungan. ${ }^{4}$ Zat warna merupakan salah satu bahan utama dalam proses pewarnaan pada penyempurnaan tekstil; sekitar 10$15 \%$ dari zat warna yang sudah digunakan tidak dapat digunakan kembali dan berakhir di tempat pembuangan dan apabila tidak dikawal dengan benar akan mencemari lingkungan di sekitarnya. ${ }^{5}$

Beberapa dampak negatif dari teknik penyempurnaan tekstil konvensional seperti yang telah dijelaskan kemudian melahirkan berbagai solusi inovatif dengan prospek yang menjanjikan baik dalam segi hasil, biaya perlakuan, maupun tingkat konsumsi energi serta keramahan terhadap lingkungan salah satunya ialah penyempurnaan tekstil dengan menggunakan teknik perlakuan oleh plasma.

Teknologi perlakuan oleh plasma ini menawarkan beberapa keunggulan yang lebih menguntungkan daripada proses kimia konvensional. ${ }^{6}$ Metode perlakuan material tekstil dengan plasma tersebut terdiri dari banyak jenis, salah satu yang paling populer adalah perlakuan plasma lucutan pijar korona. Perlakuan lucutan pijar korona telah banyak diterapkan untuk memodifikasi permukaan salah satunya polimer. ${ }^{7}$ Proses perlakuan oleh plasma memiliki kemampuan untuk mengoptimalkan sifat-sifat mikroskopik dari permukaan tekstil, beberapa di antaranya meliputi daya serap air, penyempurnaan bahan yang bersifat hidrofobik, daya ikat molekuler, kualitas produk (dapat berupa ketahanan mekanis), serta aspek kefungsian dari bahan tekstil tersebut sebagai contoh fungsi anti bakteri, anti ultraviolet ataupun fungsi lainnya yang bergantung pada jenis plasma yang digunakan. ${ }^{8}$ Dengan pemilihan gas reagen yang tepat sebagai medium terbentuknya plasma (beberapa di antaranya seperti: $\mathrm{O}_{2}, \mathrm{~N}_{2}, \mathrm{H}_{2}$, udara, Ar, $\mathrm{He}, \mathrm{NH}_{3}$, hidrokarbon, fluorokarbon) serta kontrol terhadap kondisi operasional plasma (waktu perlakuan, daya, tekanan, laju aliran gas) dapat memberikan efek intrinsik (microscopic effect) pada bahan tekstil seperti mengoptimalkan sifat hidrofilisitas atau sifat hidrofobisitas / oleofilisitas, meningkatkan reaktivitas kimia dari bahan inert alami, meningkatkan sifat adhesi pelapis, memperkaya unsur kimiawi dan gugus fungsi pada bahan serta memperkuat daya tahan mekanis. ${ }^{9}$

Teknologi perlakuan plasma dapat dinobatkan sebagai salah satu bentuk alat rekayasa permukaan bahan tekstil yang unik dan inovatif, hal ini ditinjau dari kemampuan dalam cakupan aspek fisik, kimiawi atau dalam sudut pandang termal yang dimiliki oleh teknologi perlakuan plasma sendiri seperti temperaturnya yang rendah, sifat perlakuan plasma yang kering (tidak melibatkan air), proses keseluruhan yang tidak menghasilkan limbah dan masih banyak lagi, menawarkan banyak cakupan penelitian yang baru dan inovatif di masa kini. ${ }^{10}$

Hipotesis yang dikemukakan pada penelitian ini yakni bahwa kain sutra alam (Bombyx mori) yang diberi perlakuan plasma akan mempunyai perbedaan karakteristik sifat intrinsik dibandingkan dengan kain sutra alam yang tidak diberi perlakuan akibat dari adanya fenomena-fenomena perlakuan yang terjadi. Beberapa sifat intrinsik yang perhatikan pada penelitian ini meliputi sifat mekanis (ketahanan jebol), sifat kebasahan (daya serap air) dan sifat mikroskopik (morfologi permukaan material dan gugus fungsi terkandung). Diyakini bahwa perlakuan dengan menggunakan plasma dapat mengoptimalisasi sifat-sifat intrinsik sebagaimana yang diperoleh dari hasil penelitianpenelitian sebelumnya.

\section{METODE PENELITIAN}

\section{Lokasi dan Waktu Penelitian}

Beberapa lokasi pelaksanaan penelitian secara keseluruhan mencakup:

- Laboratorium Fisika Radiasi Departemen Fisika, FSM Universitas Diponegoro 
Karakterisasi Plasma Lucutan Pijar Korona Positif pada Kondisi Atmosfer dengan Konfigurasi Elektroda Titik Bidang dan Penerapannya terhadap Kain Sutra Alam (Bombyx morl) (Mahendra Kusuma Nugraha, dkk)

- Laboratorium Kimia, FMIPA, Universitas Negeri Semarang

- Rumah Sutera Alam, Kec. Tamansari, Kab. Bogor dan

- Laboratorium Pengujian, Balai Besar Tekstil, Kota Bandung

Waktu penelitian total memerlukan waktu kerja sekitar empat bulan. Terhitung dari bulan Oktober tahun 2018 s.d. bulan Januari tahun 2019.

\section{Alat dan Bahan} berikut:

Alat dan bahan penelitian meliputi sebagai

- DC power supply

- HV probe

- Multimeter analog dan digital

- Lempeng mika

- Pipet ukur

- Stopwatch

- Akuades

\section{Skema Rangkaian Eksperimen}

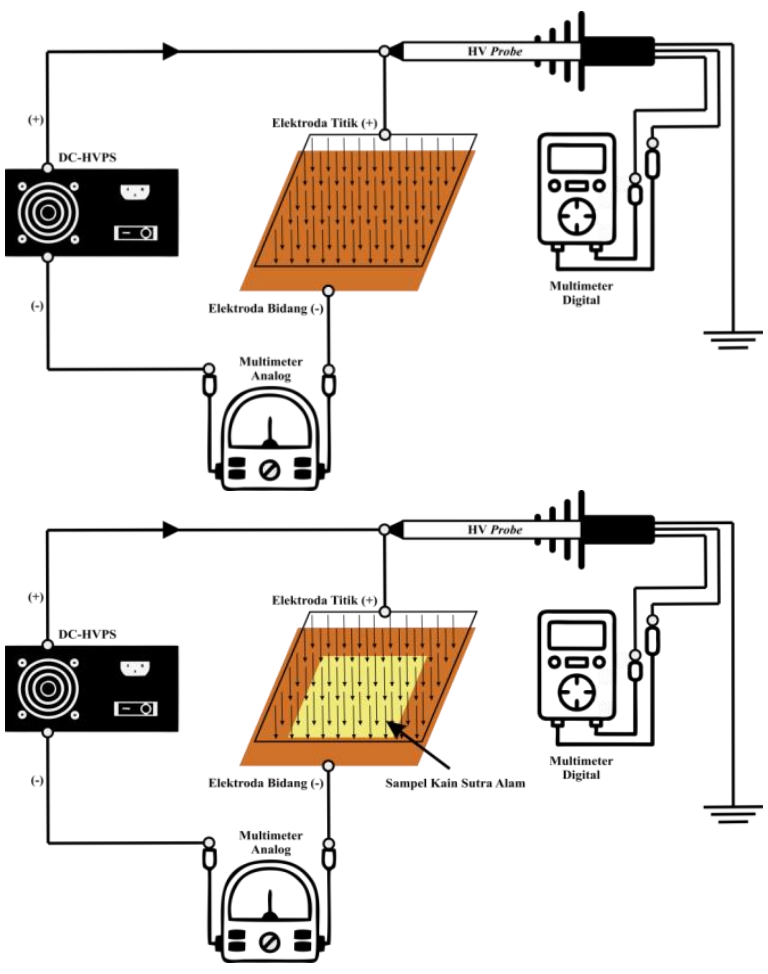

Gambar 1. Desain skema eksperimen: tanpa penempatan sampel (atas), dengan penempatan sampel (bawah)

\section{Diagram Alir}

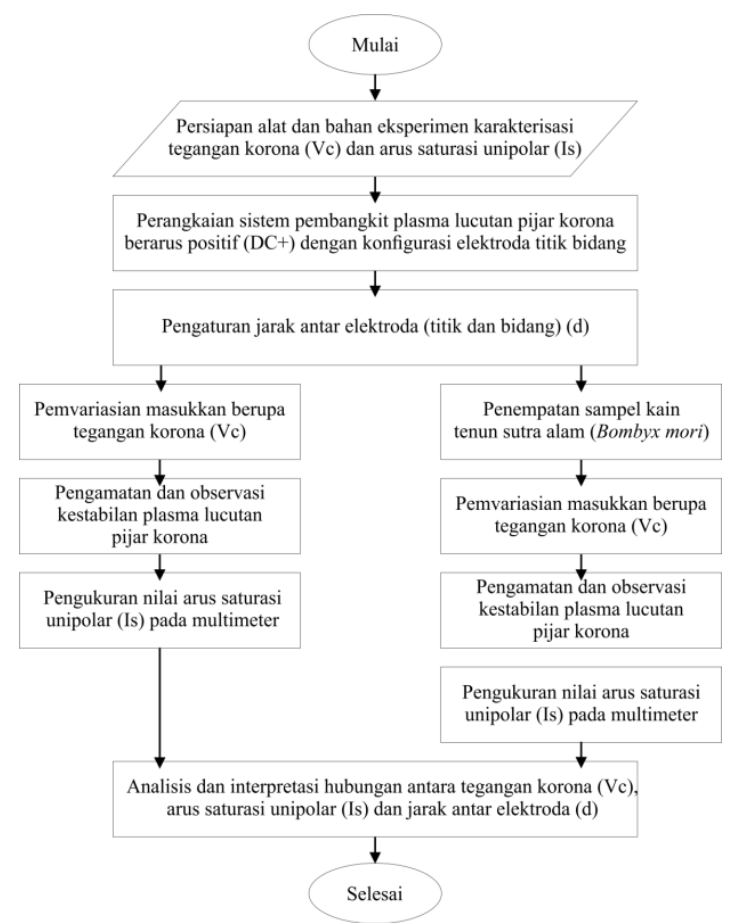

(a)

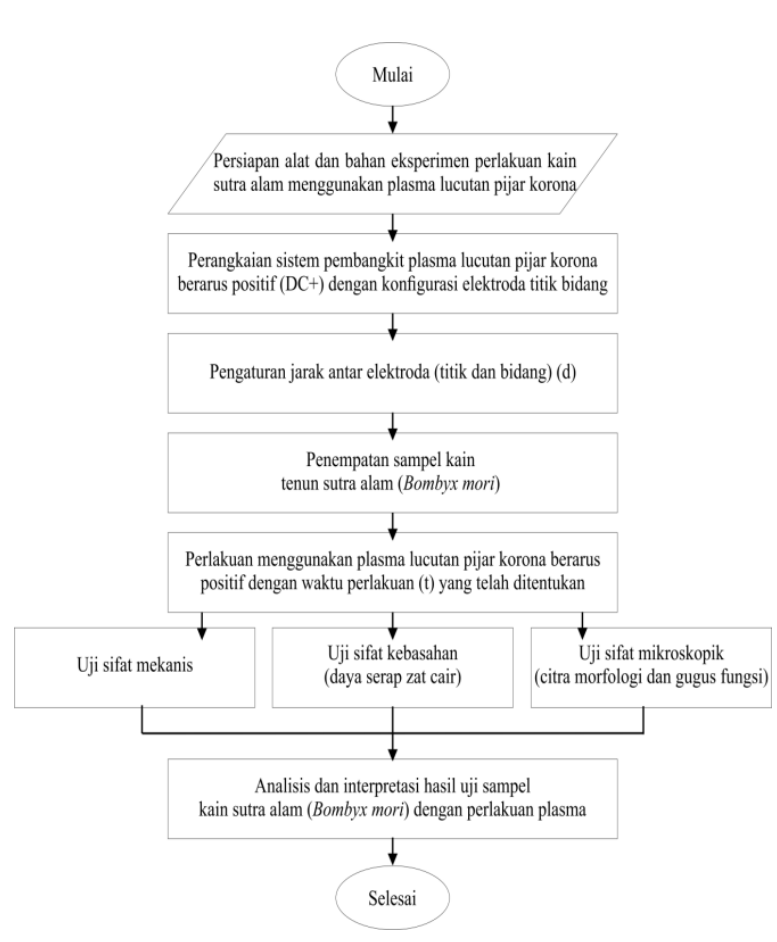

(b)

Gambar 2. Diagram alir eksperimen; tahap karakterisasi arus saturasi $\left(I_{s}\right)$ dan tegangan korona $\left(V_{c}\right) \quad$ (a), tahap perlakuan sampel kain sutra alam oleh lucutan pijar korona (b) 


\section{Prosedur Penelitian}

Prosedur penelitian keseluruhan terbagi menjadi beberapa tahap, yaitu dimulai dari observasi dan uji awal lapangan yang bertujuan untuk memastikan ketersediaan alat dan bahan serta perangkat pendukung lainnya yang akan digunakan pada saat eksperimen.

Tahap selanjutnya yakni perakitan rangkaian pembangkit plasma lucutan pijar korona dengan spesifikasi elektroda titik (anoda) terdiri dari seratus buah jarum stainless dengan panjang $2 \mathrm{~cm}$, diameter $0,5 \mathrm{~mm}$ dan jarak antar jarum $1,3 \mathrm{~cm}$. Pada elektroda bidang (katoda) digunakan PCB single copper layer dengan spesifikasi luas permukaan $400 \mathrm{~cm}^{2}$. Tahap karakterisasi hubungan arus saturasi $\left(I_{s}\right)$ dan tegangan korona $\left(V_{c}\right)$ dilakukan pada dua kondisi yakni tanpa dan dengan penempatan sampel kain sutra alam menggunakan variasi jarak antar elektroda $(d)$ dimulai dari $0,9 \mathrm{~cm}$ s.d. $3,0 \mathrm{~cm}$ dengan interval $0,3 \mathrm{~cm}$. Setelah diperoleh kondisi lucutan pijar korona yang optimal, maka dilakukan kegiatan perlakuan lucutan pijar korona pada sampel kain sutra alam (Bombyx mori) yang berukuran $100 \mathrm{~cm}^{2}$ dengan bebagai ketentuan lama waktu perlakuan dimulai dari 15 menit s.d. 40 menit dengan interval 5 menit.

Tahap pengujian sifat intrinsik dilaksanakan untuk mengetahui pengaruh perlakuan plasma terhadap nilai ketahanan jebol, nilai rata-rata waktu serap $(\tau)$ akuades dan perubahan struktur permukaan serta pengaruh terhadap keberadaan gugus fungsi terkandung pada sampel kain sutra alam yang telah diberi perlakuan dan membandingkan hasil pengujian terhadap sampel tanpa perlakuan (kontrol). Tahap terakhir yakni melakukan analisis dan interpretasi data pengukuran hasil karakterisasi hubungan arus saturasi $\left(I_{s}\right)$ terhadap tegangan korona $\left(V_{c}\right)$ dan data hasil pengujian ketiga sifat intrinsik yang telah dilakukan.

\section{HASIL DAN PEMBAHASAN}

\section{Karakterisasi Arus Saturasi $\left(I_{s}\right)$ dan Tegangan Korona $\left(V_{c}\right)$}

Pada tahap eksperimen ini, dibangkitkan plasma lucutan pijar korona menggunakan sumber tegangan tinggi arus searah (DC-HVPS) pada rangkaian pembangkit plasma lucutan pijar korona dengan konfigurasi elektroda titik dan bidang masing-masing sebagai anoda dan katoda. Kemudian dilakukan kegiatan pencarian hubungan arus saturasi unipolar $\left(I_{s}\right)$ dan tegangan korona $\left(V_{c}\right)$ dengan cara mengukur nilai arus saturasi yang muncul sebagai variabel terikat terhadap tegangan korona yang diberikan oleh DC-HVPS sebagai variabel bebas.

Jika diperhatikan pada grafik karakteristik hubungan arus saturasi $\left(I_{s}\right)$ dan tegangan korona $\left(V_{c}\right)$ pada Gambar 3 dan Gambar 4, nilai arus yang terukur akan terus mengalami kenaikan sesuai dengan besaran nilai tegangan yang diberikan pada rangkaian. Kenaikan arus saturasi $\left(I_{s}\right)$ ini akan membentuk pola yang cenderung konstan (apabila kondisi eksperimen pada saat itu cukup mendukung).

Nilai tegangan yang terukur ini disebut juga sebagai discharge voltage, karena pada saat berada dalam daerah ini, arus listrik dapat mengalir dari elektroda titik (anoda) menuju ke elektroda bidang (katoda) akibat dari pengaruh medan listrik yang muncul dan mengionisasi elektron-elektron pada atom/ molekul gas medium udara bebas sehingga menjadi bersifat menghantarkan listrik.

Elektron bebas yang berada di sekitar medan listrik ini akan memiliki cukup energi untuk bergerak dan menumbuk atom/ molekul gas di sekitarnya dan menyebabkan peristiwa ionisasi yang menghasilkan ion positif, spesies radikal dan elektron bebas lainnya. ${ }^{11}$

Pada masing-masing variasi jarak antar elektroda $(d)$, dapat dilihat bahwa pola kenaikan arus saturasi mengikuti besaran tegangan yang diberikan, ditandai dengan adanya lucutan Townsend di awal, kemudian dilanjutkan dengan lucutan pijar korona hingga nantinya akan mencapai suatu titik di mana terjadi peristiwa pendadalan elektrik (electrical breakdown) yang menimbulkan lucutan arc. ${ }^{12}$ Lucutan arc yang muncul ini ditandai oleh meningkatnya arus saturasi secara signifikan pada waktu yang singkat (instan) dan nilai tegangan pada rangkaian menurun dengan drastis. Ketika besaran tegangan yang cukup tinggi diterapkan pada gas yang terdifusi (atau campuran gas) pada celah antara sepasang elektroda pada reaktor plasma non termal, gas akan mengalami pendadalan listrik dan secara aktif menjadi berkemampuan untuk menghantarkan listrik. ${ }^{13}$

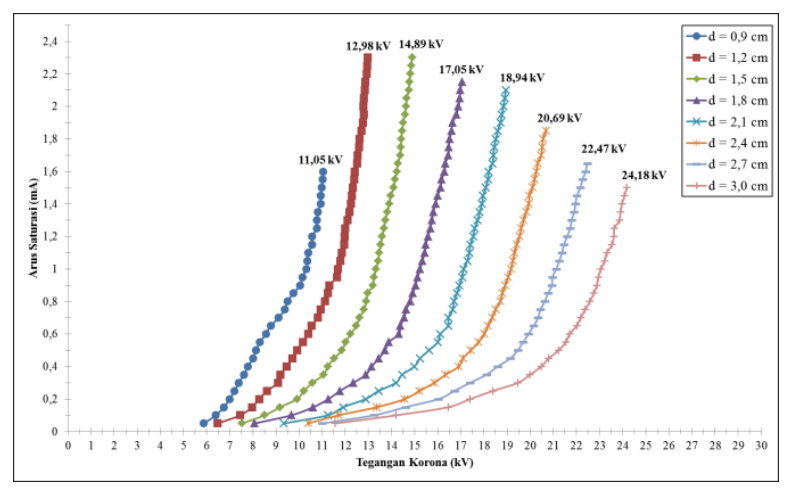

Gambar 3. Grafik karakteristik hubungan $I_{s}-V_{c}$ tanpa penempatan sampel berdasarkan variasi $d$

Jarak antar elektroda $(d)$ juga berpengaruh pada nilai arus saturasi $\left(I_{s}\right)$ yang terukur pada masing-masing tegangan lucutan, dapat dilihat dari nilai arus yang sama pada setiap jarak. Ini berarti bahwa energi kinetik elektron yang dibutuhkan untuk melakukan perjalanan serta melakukan proses 
ionisasi, eksitasi dan deeksitasi atom / molekul gas medium dari katoda menuju anoda akan semakin tinggi apabila jarak kedua elektroda diperbesar, sehingga untuk mempertahankan laju arus listrik yang tetap pada besaran tertentu dengan jarak antar elektroda yang bervariasi membutuhkan besaran beda potensial yang berbeda.

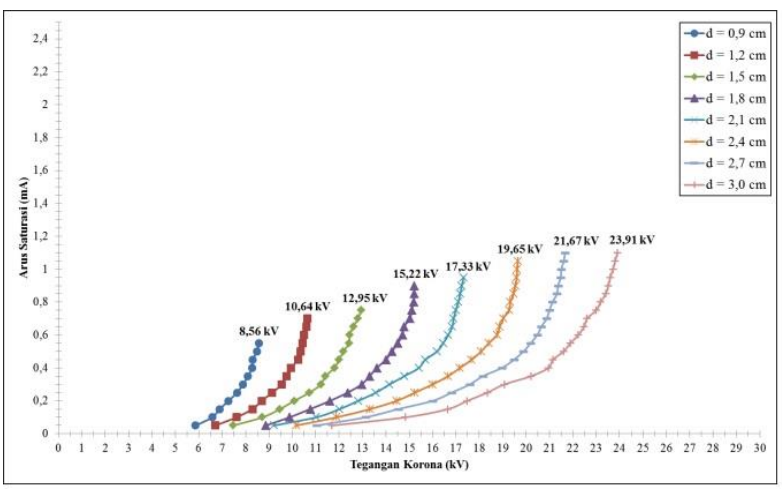

Gambar 4. Grafik karakteristik hubungan $I_{s}-V_{c}$ dengan penempatan sampel berdasarkan variasi $d$

Pada Gambar 4, dapat diperhatikan bahwa pada masing-masing jarak antar elektroda, tegangan puncak yang terukur seluruhnya berada di bawah nilai tegangan puncak pada tahap karakterisasi sebelumnya, ini merupakan bukti nyata dari pengaruh penempatan sampel kain sutra dalam segi besaran fisis yang terukur dari plasma lucutan pijar korona yang terbentuk pada konfigurasi titik dan bidang.

Hal ini mengarah pada satu penjelasan bahwa dengan adanya penempatan sampel ini, pergerakan elektron dan ion di antara anoda dan katoda cenderung lebih cepat mengalami kejenuhan dan lucutan arc lebih mudah muncul pada rangkaian pada kondisi di mana pada tahap sebelumnya belum terjadi. Setelah besaran tegangan dan arus cukup untuk mencapai kondisi pendadalan elektrik di antara sepasang elektroda, dihasilkan sejumlah besar lucutan seperti busur listrik yang dikenal sebagai microdischarges. ${ }^{13}$

\section{Perhitungan Mobilitas Pembawa Muatan ( $\mu$ )}

Interpretasi grafik hubungan jarak antar elektroda $(d)$ terhadap mobilitas pembawa muatan ( $\mu$ ) pada lucutan pijar korona menunjukkan pola hasil perhitungan yang saling bertolak belakang antara kondisi tanpa penempatan dan dengan penempatan sampel seperti pada Gambar 5.

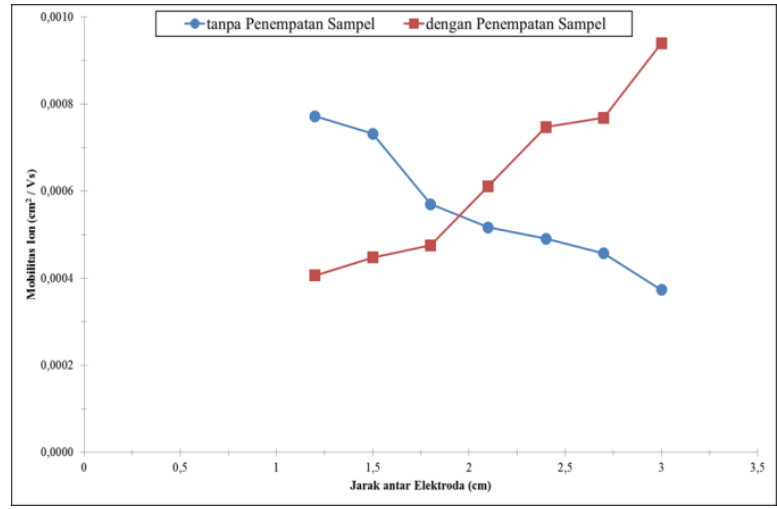

Gambar 5. Grafik hubungan besaran jarak antar elektroda $(d)$ terhadap mobilitas ion pembawa muatan $(\mu)$ pada lucutan pijar korona

Pada kondisi tanpa penempatan sampel, nilai mobilitas pembawa muatan $(\mu)$ yang terhitung cenderung menurun sebanding dengan jarak antar elektroda $(d)$ yang digunakan mulai dari $0,9 \mathrm{~cm}$ hingga $3,0 \mathrm{~cm}$, kecuali pada jarak $0,9 \mathrm{~cm}$ di mana nilai $\mu$ terhitung jauh lebih rendah dibandingkan nilai $\mu$ terhitung pada penggunaan variasi $d$ yang lebih tinggi.

Adanya kecenderungan menurunnya nilai terhitung dari $\mu$ tersebut kemungkinan besar disebabkan oleh pengaruh jarak antar elektroda yang semakin jauh sehingga menyebabkan pergerakan elektron, ion dan spesies radikal yang terbentuk menjadi semakin lambat. Dengan menggunakan analisis yang sama, dapat dipahami bahwa pada kondisi dengan penempatan sampel, berkebalikan dari sebelumnya, nilai mobilitas pembawa muatan $(\mu)$ yang terhitung cenderung meningkat mulai dari jarak antar elektroda $(d)$ 1,2 $\mathrm{cm}$ hingga $3,0 \mathrm{~cm}$ maka diperoleh pola peningkatan nilai mobilitas pembawa muatan $(\mu)$ yang sebanding dengan besarnya jarak antar elektroda $(d)$ yang digunakan.

Salah satu faktor yang mempengaruhi nilai perhitungan $\mu$ tersebut diyakini karena adanya interaksi antara ion-ion positif yang mengalir dari ujung elektroda titik dengan atom/ molekul yang berada pada permukaan material. Sifat tidak menghantarkan listrik dari kain sutra diduga juga berpengaruh pada kenaikan nilai mobilitas pembawa muatan $(\mu)$ pada kondisi lucutan pijar korona dengan penempatan sampel. Partikel pembawa muatan dalam sebuah materi ketika berada dalam pengaruh medan listrik akan mengalami pergerakan dengan kecepatan rata-rata yang disebut dengan drift velocity. Besarnya drift velocity tersebut berbanding lurus dengan kuat medan listrik pada sistem dan nilai mobilitas dari partikel pembawa muatan. ${ }^{14}$ 


\section{Penentuan Karakteristik Optimal Lucutan Pijar Korona}

Tabel 1. Karakteristik optimal lucutan pijar korona tanpa penempatan sampel

\begin{tabular}{ccc}
\hline $\begin{array}{c}\text { Jarak antar } \\
\text { Elektroda }(d)\end{array}$ & $\begin{array}{c}\text { Tegangan } \\
\text { Korona }\left(V_{c}\right)\end{array}$ & $\begin{array}{c}\text { Arus Saturasi } \\
\left(I_{s}\right)\end{array}$ \\
\hline $2,1 \mathrm{~cm}$ & $\pm 18 \mathrm{kV}$ & $1,5 \mathrm{~mA}$ \\
$2,4 \mathrm{~cm}$ & $\pm 20 \mathrm{kV}$ & $1,5 \mathrm{~mA}$ \\
\hline
\end{tabular}

Tabel 2. Karakteristik optimal lucutan pijar korona dengan penempatan sampel

\begin{tabular}{ccc}
\hline Jarak antar & Tegangan & Arus Saturasi \\
Elektroda $(d)$ & Korona $\left(V_{c}\right)$ & $\left(I_{s}\right)$ \\
\hline $2,1 \mathrm{~cm}$ & $\pm 17 \mathrm{kV}$ & $0,75 \mathrm{~mA}$ \\
$2,4 \mathrm{~cm}$ & $\pm 19,5 \mathrm{kV}$ & $1,0 \mathrm{~mA}$ \\
\hline
\end{tabular}

Tabel 1 dan 2 menginformasikan beberapa karakteristik optimal lucutan pijar korona yang terbentuk berdasarkan interpretasi grafik karakteristik hubungan arus saturasi $\left(I_{s}\right)$ dan tegangan korona $\left(V_{c}\right)$ baik tanpa penempatan sampel ataupun dengan penempatan sampel kain sutra alam. Karakteristik lucutan pijar korona tersebut kemudian dipilih sebagai karakteristik yang optimal untuk proses perlakuan kain sutra alam (Bombyx mori) berdasarkan beberapa sudut pandang. Pertama, kestabilan lucutan pijar korona dalam segi besaran fisis yang terukur, pada masingmasing jarak antar elektroda (d) yang digunakan, dipilih tiga variasi jarak yang fluktuasi nilai arus saturasi $\left(I_{s}\right)$ terukur paling tidak signifikan terhadap besaran tegangan korona $\left(V_{c}\right)$ yang diberikan, sehingga arus yang terukur dapat dipertahankan pada angka tertentu dalam waktu yang cukup lama sesuai dengan tegangan yang diberikan. Kedua, dalam menentukan ciri khas lucutan pijar korona yang optimal, juga dapat dilakukan pengamatan visual dari plasma yang terbentuk pada reaktor pembangkit plasma. Lucutan pijar korona ditandai dengan munculnya berkas cahaya tampak berwarna keunguan yang membentuk pola hiperbolik (pada kasus lucutan pijar korona positif) di antara kedua elektroda serta menimbulkan suara desis yang dapat terdengar jelas.

Dari informasi yang tertera pada Tabel 2, akan dipilih salah satu atau dua kondisi karakteristik optimal plasma lucutan pijar korona positif yang terbentuk untuk digunakan sebagai parameter perlakuan sampel kain sutra alam (Bombyx mori) pada tahap penelitian selanjutnya.

Perlu diketahui bahwa nilai mobilitas pembawa muatan $(\mu)$ yang telah diketahui melalui perhitungan pada kondisi lucutan pijar korona tidak menjadi salah satu pertimbangan dalam menentukan karakteristik lucutan yang optimal. Hal ini dikarenakan masih perlu banyak pembelajaran dan eksperimen berkelanjutan dengan perolehan data yang konsisten untuk dapat menghubungkan besaran mobilitas pembawa muatan $(\mu)$ terhadap representasi plasma lucutan pijar korona yang optimal, sehingga untuk sementara, hanya dengan memperhatikan ciri khas secara makroskopik yang muncul dianggap sudah cukup untuk mewakili pembentukan kondisi plasma lucutan pijar korona yang stabil dan optimal.

\section{Hasil Pengujian Sifat Mikroskopik}

Pada tahap analisis hasil pengujian citra morfologi/ tekstur permukaan oleh SEM dalam subbab ini, adapun spesifikasi perlakuan oleh plasma pada kain sutra alam yang digunakan sebagai objek pengujian dengan SEM meliputi; lama waktu perlakuan $(t)$ sebesar 0 menit (kontrol), 25 menit dan 35 menit, jarak antar elektroda $(d)$ yang digunakan setinggi $2,4 \mathrm{~cm}$ dan kuat arus saturasi $\left(I_{s}\right)$ dipertahankan pada angka $1,0 \mathrm{~mA}$. Hasil pengujian sifat mikroskopik dengan metode pencitraan SEM pada sampel kain sutra alam tanpa perlakuan oleh plasma disajikan pada Gambar 6a.

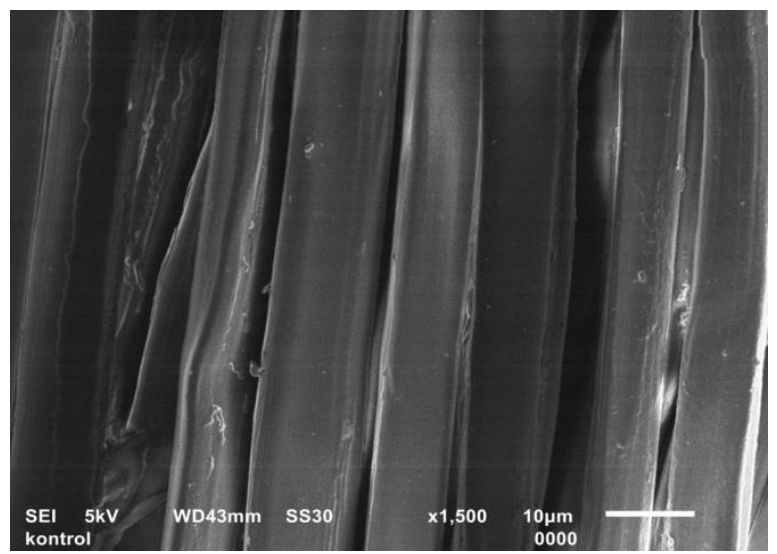

(a)

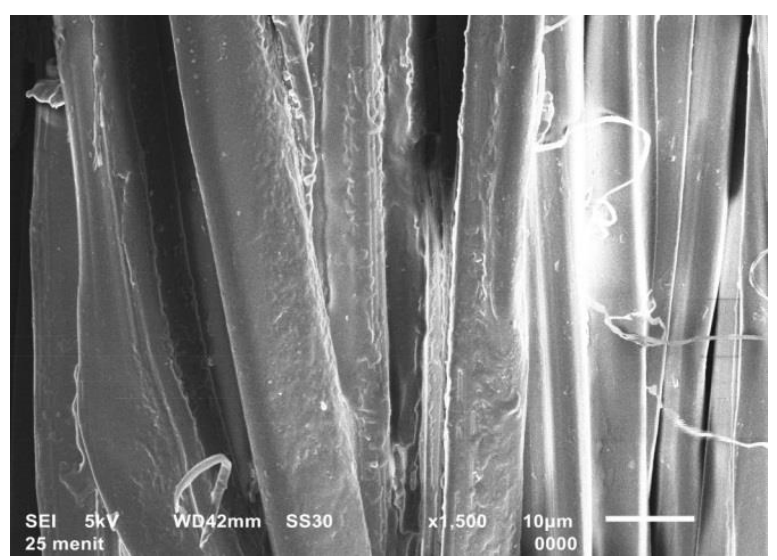

(b)

Gambar 6. Hasil pencitraan SEM pada sampel kain sutra alam: tanpa perlakuan (a) dan dengan perlakuan plasma selama 25 menit (b) 
Dapat diidentifikasi bahwa ada perbedaan struktur morfologi yang cukup signifikan antara sampel kontrol dan sampel yang telah diberi perlakuan oleh plasma lucutan pijar korona. Hal ini ditunjukkan dengan adanya retakan-retakan kecil (microcracks), lepuhan (blisters) serta robekan (rips) pada serat kain sutra alam yang telah diberi perlakuan oleh plasma. Penyebab utamanya dikarenakan oleh peristiwa tumbukan antara ion-ion pembawa muatan yang dihasilkan dalam proses plasma dengan permukaan sampel kain sutra alam yang diletakkan di bagian katoda. Sebanding dengan lamanya waktu perlakuan $(t)$ maka pembentukan retakan dan lepuhan ini semakin banyak dan pada akhirnya mengakibatkan pengikisan dan kerusakan pada permukaan sampel secara signifikan seperti yang terlihat pada Gambar $6 b$.

Permukaan material yang terlihat rusak ataupun terkikis disebabkan oleh penghilangan material permukaan atau yang dikenal sebagai proses pengetsaan (etching). ${ }^{15}$ Diyakini bahwa dengan adanya retakan dan lepuhan pada permukaan sampel yang telah diberi perlakuan tersebut bertanggung jawab terhadap peningkatan sifat kebasahan akibat dari pembentukan permukaan yang menjadi lebih kecil dan berongga sehingga molekul air lebih mudah mengalami absorbsi. Akibat dari perlakuan oleh plasma, retakan-retakan kecil menonjol yang terbentuk dari proses pengetsaan pada permukaan material menyebabkan adanya peningkatan tekstur kekasaran permukaannya. Perlakuan oleh plasma juga dapat menghilangkan lapisan hidrofobik yang berada di permukaan paling atas dan secara otomatis memperbesar energinya, sehingga material tersebut menjadi bersifat hidrofilik. ${ }^{16}$

Hasil pengujian spektroskopi FTIR pada sampel kain sutra alam hasil perlakuan plasma lucutan pijar korona dengan spesifikasi perlakuan meliputi lama waktu perlakuan $(t)$ sebesar 0 menit (kontrol), 25 menit dan 35 menit, jarak antar elektroda $(d)$ yang digunakan setinggi $2,4 \mathrm{~cm}$ dan kuat arus saturasi $\left(I_{s}\right)$ dipertahankan pada angka 1,0 $\mathrm{mA}$ dan sampel kain sutra alam kontrol disajikan pada interpretasi grafik perbandingan karakteristik persentase transmitansi $(\% \mathrm{~T})$ terhadap bilangan gelombang pada Gambar 7.

Dapat dilihat bahwa pola persentase transmitansi (\%T) dari berkas inframerah yang dikenakan memiliki bentuk yang hampir serupa antara satu dengan yang lainnya. Hal ini berarti bahwa hasil spektroskopi FTIR pada kedua sampel kain sutra alam (Bombyx mori) menunjukkan kandungan jenis gugus fungsi yang sama (tidak ada penambahan gugus fungsi baru pada sampel kain sutra alam yang diberi perlakuan), akan tetapi nilai persentase transmitansi yang berbeda di tiap lembah pada masing-masing nilai bilangan gelombang yang bersesuaian menjelaskan bahwa ada perbedaan konsentrasi dari jenis gugus fungsi yang terkandung.

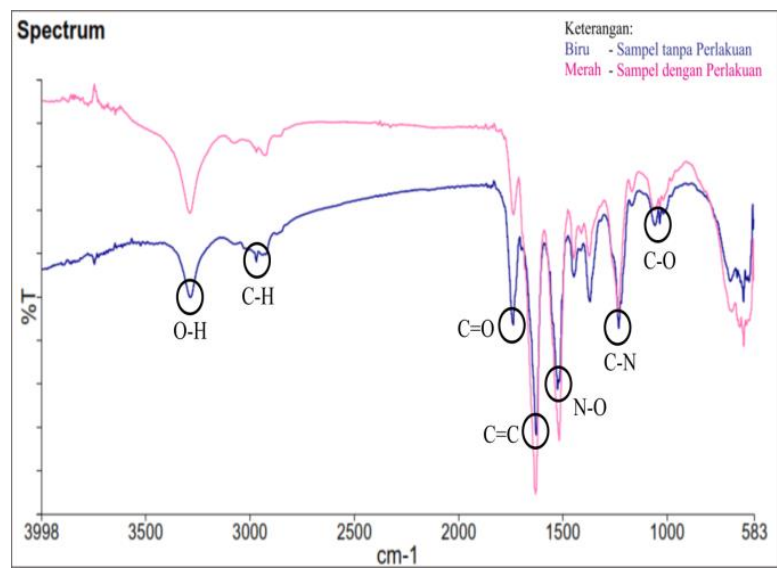

Gambar 7. Grafik karakteristik persentase transmitansi (\% T) terhadap bilangan gelombang pada sampel kain sutra alam kontrol (biru) dan dengan perlakuan plasma (merah)

Beberapa jenis gugus fungsi utama yang dapat diidentifikasi dari hasil interpretasi spektroskopi FTIR pada kedua sampel kain sutra alam (Bombyx mori) di antaranya yakni: C-O (alkohol), $\mathrm{C}-\mathrm{N}$ (amina), $\mathrm{C}=\mathrm{C}$ (alkena), $\mathrm{C}=\mathrm{O}$ (aldehid), $\mathrm{C}-\mathrm{H}$ (alkana) dan $\mathrm{O}-\mathrm{H}$ (asam karboksilat).

Oksigen dan nitrogen yang dihasilkan pada plasma udara (atmospheric plasma) dapat dengan mudah berinteraksi dengan zat selulosa yang kemudian berdampak pada pembentukan gugus fungsi $\mathrm{C}-\mathrm{N}$ atau $\mathrm{C}=\mathrm{O}$ ataupun pemutusan gugus fungsi C-H. ${ }^{15}$

Perbedaan konsentrasi gugus fungsi terkandung pada sampel kain sutra alam yang telah diberi perlakuan dapat disebabkan karena adanya perbedaan kemampuan absorbansi yang dimiliki oleh gugus fungsi terkandung di dalamnya. Dapat dilihat perbandingannya pada sampel kontrol dan sampel perlakuan terhadap gugus fungsi O-H (asam karboksil, dengan $\lambda_{T}$ masing-masing $3286,8 \mathrm{~cm}^{-1}$ dan $3290 \mathrm{~cm}^{-1}$ ) dan gugus fungsi C-H (alkana, dengan $\lambda_{T}$ masing-masing $2972,6 \mathrm{~cm}^{-1}$ dan 2973,9 $\mathrm{cm}^{-1}$ ) yang menunjukkan bahwa sampel kontrol memiliki kemampuan absorbansi lebih tinggi dibandingkan sampel hasil perlakuan menggunakan plasma lucutan pijar korona. Gugus fungsi $\mathrm{O}-\mathrm{H}$ memiliki sifat polar sehingga berperan penting dalam menentukan sifat kebasahan (hidrofilisitas) suatu material ditinjau dari konsentrasi gugus fungsi yang bersangkutan.

Beberapa jenis gugus fungsi yang berpengaruh pada sifat swelling (yakni sifat penyerapan air pada polimer superabsorben) di 
antaranya adalah gugus $-\mathrm{OH},-\mathrm{NH}_{2},-\mathrm{COOH}$, $\mathrm{CONH}$ dan $-\mathrm{SO}_{3} \mathrm{H}^{17}$

Pengaruh perbedaan kandungan gugus fungsi baik yang bersifat polar pada sampel kain sutra alam dengan perlakuan dan tanpa perlakuan akan dibuktikan pada tahap pengujian sifat intrinsik selanjutnya.

\section{Hasil Pengujian Sifat Mekanis}

Berdasarkan interpretasi yang disajikan pada Gambar 8, dapat dilihat secara jelas bahwa nilai ketahanan jebol minimum yang dimiliki oleh sampel kain sutra alam (Bombyx mori) setelah diberi perlakuan pada masing-masing jarak antar elektroda $(d)$ dan waktu perlakuan $(t)$ yang digunakan lebih rendah dibandingkan dengan nilai ketahanan jebol yang dimiliki oleh sampel kain sutra alam yang tidak diberi perlakuan. Nilai ketahanan jebol yang terukur oleh mesin pengujian cenderung fluktuatif pada masing-masing variasi yang digunakan, ini berkaitan dengan kemampuan yang dimiliki oleh lucutan pijar korona yang dapat mendegradasi ataupun mengikis permukaan material ${ }^{[15]}$ akibat bertumbukan dengan partikelpartikel pembawa muatan yang terbentuk akibat guguran elektrik yang terjadi pada lucutan pijar korona sehingga menyebabkan perubahan struktur serat kain sutra alam yang diberi perlakuan.

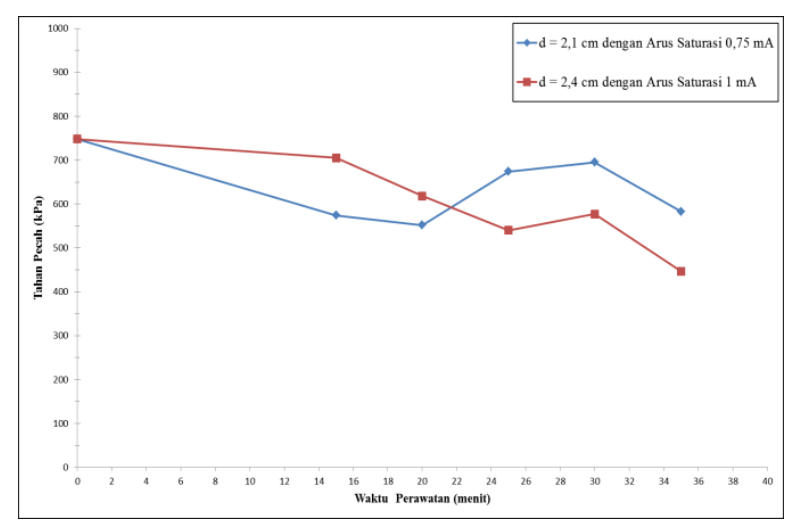

Gambar 8. Grafik karakteristik hubungan nilai ketahanan pecah terhadap waktu perlakuan $(t)$ menggunakan plasma lucutan pijar korona

Perlakuan dengan menggunakan plasma membuat serat yang berada di permukaan paling atas menjadi lebih rapuh akibat proses pengetsaan sehingga mudah mengalami perpecahan. ${ }^{15}$ Perlakuan dengan plasma juga dapat mengubah permukaan serat polipropilena. ${ }^{18}$ Ini dikarenakan kemampuan plasma dalam memodifikasi permukaan suatu material yang diteliti. Fenomena pengetsaan mengakibatkan pembentukan cerukceruk yang mempengaruhi sifat penyerapan air yang lebih tinggi sehingga membuat permukaannya lebih kasar dan melancarkan aksesibilitas zat cair. ${ }^{19}$
Perlu diperhatikan pula bahwa dengan memilih penggunaan karakteristik lucutan yang tepat untuk meminimalisir kerusakan dan pengikisan (ataupun kerugian sifat mekanis yang lain) terhadap sampel juga belum tentu dapat mengoptimalkan sifat-sifat intrinsik lainnya seperti sifat kebasahan, sehingga memang beberapa parameter keberhasilan dari perlakuan harus dikorbankan untuk memperoleh hasil perlakuan yang paling sesuai dengan kebutuhan yang diinginkan. Maka dari itu, karakteristik perlakuan dengan variasi jarak antar elektroda (d) sebesar $2,1 \mathrm{~cm}$, arus saturasi sebesar $0,75 \mathrm{~mA}$ dan lama waktu perlakuan yakni 30 menit merupakan kondisi yang paling optimal dalam perolehan hasil pengujian nilai ketahanan jebol yang nilainya tidak terpaut jauh dari nilai yang terukur pada sampel kontrol.

\section{Hasil Pengujian Sifat Kebasahan}

Berdasarkan grafik karakteristik hubungan nilai rata-rata waktu serap $(\tau)$ terhadap waktu perlakuan $(t)$ yang disajikan pada Gambar 9, terlihat bahwa pola penurunan rata-rata waktu serap $(\tau)$ sebanding dengan lamanya waktu perlakuan $(t)$ yang diberikan. Ini membuktikan bahwa dengan adanya perlakuan oleh plasma lucutan pijar korona terhadap sampel kain sutra alam mampu meningkatkan daya basah lebih besar dibandingkan dengan tanpa adanya perlakuan. Peningkatan sifat hidrofilisitas kain sutra alam akibat perlakuan oleh lucutan pijar korona dilatar belakangi oleh kemampuan plasma untuk mengaktivasi permukaan bahan atau material ${ }^{[20]}$ yang kemudian dapat mengoptimalkan sifat-sifat mikroskopik material salah satunya yakni daya basah atau wettability. ${ }^{8}$

Dengan adanya penempatan sampel di atas permukaan katoda, maka pembawa muatan yang bergerak menuju katoda harus melewati material sampel sehingga peristiwa penumbukan pun terjadi. Tumbukan dengan pembawa muatan ini dapat mengetsa dan merusak permukaan material sehingga susunan/teksturnya dapat berubah.

Sifat absorbansi (daya serap) terhadap zat cair dari kain (yang diukur dalam waktu serap atau sudut kontak) meningkat ketika sampel kain diberi perlakuan oleh plasma. $^{15}$ Dengan kata lain, perlakuan plasma terbukti efisien dalam meningkatkan kapasitas penyerapan dengan tujuan untuk memaksimalkan sifat hidrofilik. ${ }^{19}$

Dari perolehan hasil uji daya serap zat cair, dapat ditarik sebuah argumen bahwa peristiwa pengikisan dan kerusakan pada permukaan sampel kain sutra alam akibat perlakuan oleh plasma memiliki pengaruh yang lebih signifikan terhadap daya serap zat cair pada sampel tersebut dibandingkan dengan pengaruh kandungan gugus fungsi hidrofilik pada sampel kain sutra alam. Hal ini dibuktikan dengan rata-rata waktu serap akuades pada sampel kain sutra alam dengan perlakuan (di 
mana konsentrasi gugus fungsi polar yang terkandung lebih kecil) dan lebih singkat dibandingkan dengan sampel kain sutra alam kontrol (di mana konsentrasi gugus fungsi polar lebih besar).

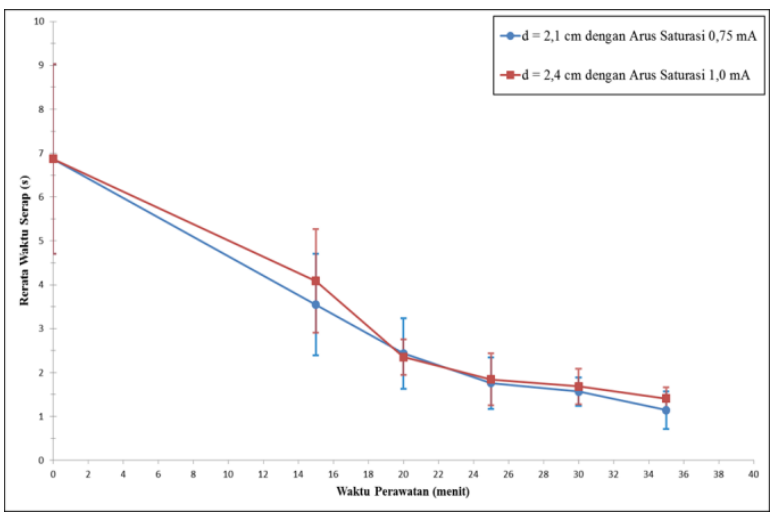

Gambar 9. Grafik karakteristik hubungan nilai rata-rata waktu serap $(\tau)$ terhadap waktu perlakuan $(t)$ menggunakan plasma lucutan pijar korona

Jika dikaitkan dengan karakteristik lucutan yang digunakan terhadap sampel kain sutra alam pada tahap pengujian sifat mekanis yakni jarak antar elektroda $(d)$ sebesar $2,1 \mathrm{~cm}$, arus saturasi $\left(I_{s}\right)$ $0,75 \mathrm{~mA}$ dan waktu perlakuan $(t)$ selama 20 dan 30 menit, dapat dilihat bahwa rata-rata waktu serap $(\tau)$ menunjukkan kecepatan penyerapan yang lebih singkat pada kondisi lama waktu perlakuan $(t)$ di angka 30 menit (walaupun magnitude $\tau$ antara keduanya tidak terpaut jauh).

Dengan demikian, karakteristik lucutan dengan jarak antar elektroda $(d)$ sebesar $2,1 \mathrm{~cm}$, arus saturasi $\left(I_{s}\right)$ sebesar $0,75 \mathrm{~mA}$ dan waktu perlakuan $(t)$ selama 30 menit adalah karakteristik lucutan yang paling optimal untuk digunakan sebagai media perlakuan pada sampel kain sutra alam (Bombyx mori).

\section{KESIMPULAN}

1. Plasma lucutan pijar korona berarus positif terbentuk secara optimal pada jarak antar elektroda $(d)$ setinggi $2,1 \mathrm{~cm}$ dan $2,4 \mathrm{~cm}$ dan arus saturasi $\left(I_{s}\right)$ sebesar $0,75 \mathrm{~mA}$ dan $1,0 \mathrm{~mA}$ yang digunakan sebagai dua (2) karakteristik lucutan untuk perlakuan sampel kain sutra alam.

2. Terjadi penurunan nilai ketahanan jebol pada sampel kain sutra alam (Bombyx mori) yang diberi perlakuan plasma dibandingkan dengan nilai ketahanan jebol pada sampel kain sutra tanpa perlakuan plasma.

3. Terjadi penyingkatan nilai rata-rata waktu serap $(\tau)$ zat cair (akuades) pada sampel kain sutra alam (Bombyx mori) yang diberi perlakuan plasma dibandingkan dengan nilai rata-rata waktu serap $(\tau)$ pada sampel kain sutra tanpa perlakuan plasma.
4. Perlakuan dengan keoptimalan maksimum atas pertimbangan hasil uji nilai ketahanan jebol dan daya serap akuades $(\tau)$ pada sampel kain sutra alam dicapai oleh karakteristik lucutan pijar korona dengan jarak antar elektroda $(d)$ sebesar $2,1 \mathrm{~cm}$, arus saturasi $\left(I_{s}\right)$ sebesar $0,75 \mathrm{~mA}$ dan waktu perlakuan $(t)$ selama 30 menit.

5. Hasil pengujian sifat mikroskopik pada sampel kain sutra alam yang diberi perlakuan plasma membuktikan bahwa:

a. adanya perubahan struktur permukaan serat pada sampel cukup berpengaruh terhadap nilai ketahanan jebol dan rerata waktu penyerapan $(\tau)$ zat cair (akuades) dan

b. tidak ditemukan adanya penambahan jenis baru dari gugus fungsi terkandung pada sampel yang disebabkan oleh perlakuan plasma

\section{UCAPAN TERIMA KASIH}

Penulis mengucapkan terimakasih kepada seluruh jajaran tenaga pendidik di Labotarium Ekologi; Dept. Fisika; Indonesia Center for Plasma Research; Universitas Diponegoro, kepada Kepala Laboratorium Pengujian; Balai Besar Tekstil dan kepada Bapak Ir. Dudut Prasetyo MBA selaku pemilik Rumah Sutera Alam Bogor serta pihak lainnya yang tidak dapat disebutkan satu-satu atas dukungan dan bantuan dalam menjalankan kegiatan penelitian secara keseluruhan.

\section{PUSTAKA}

1. S. A. Dar, R. Akhter, and S. N. Geelani, "Impact of sericulture industry on Jammu and Kashmir Economy: (With Special reference to District Baramulla)," Int. J. Multidiscip. Educ. Res., 2(2), 60-64 (2017).

2. D. (IPB/ D. I. E. Gustiani and P. (IPB/ D. I. E. Hutagaol, "Analisis Keunggulan Komparatif dan Kompetitif Kain Tenun Sutera Produksi Kabupaten Garut (Studi Kasus pada Perusahaan PT. Aman Sahuri) di Kabupaten Garut Provinsi Jawa Barat))," J. Agribisnnis dan Ekon. Pertan., 3(2), 58-68 (2009).

3. M. Nurhaedah and A. R. H. Bisjoe, "Budidaya Ulat Sutera di Desa Sudu, Kecamatan Alla, Kabupaten Enrekang, Sulawesi Selatan," $J$. Penelit. Hutan Tanam., 10(4), 229-239 (2013).

4. A. W. Sana, E. Novarini, U. Prayudie, and R. Marlina, "Studi Penggunaan Mesin Pencelupan Sistem Jet Tie Soft Flow untuk Pencelupan Kain Poliester dan Kain Rayon," Arena Tekst., 30(1), 1-12 (2015).

5. H. Christian, E. Suwito, T. A. Ferdian, T. Setiadi, and S. H. Suhardi, "Kemampuan Pengolahan Warna Limbah Tekstil oleh Berbagai Jenis Fungi dalam Suatu Bioreaktor," 
Semin. Nas. Fundam. dan Apl. Tek. Kim., no. November, 1-6 (2007).

6. A. I. Susan, M. Widodo, and M. Nur, "Corona Glow Discharge Plasma Treatment for Hidrophylicity Improvement of Polyester and Cotton Fabrics," IOP Conf. Ser. Mater. Sci. Eng., 214(1), 1-10 (2017).

7. P. Ma, "Sizing and dyeing property improvement of cotton fabric treated with corona discharge," Asian J. Chem., 24(9), 3833-3836 (2012).

8. A. Sjaifudin T. and K. H. Sitohang, "Rancang Bangun Prototipe Mesin Plasma Tekstil Lucutan Korona Pada Tekanan Atmosfer Skala Laboratorium," Arena Tekst., 30(1), 25-36 (2015).

9. M. Radetic, P. Jovancic, N. Puac, and Z. L. Petrovic, "Environmental impact of plasma application to textiles," J. Phys. Conf. Ser., 71(1), 1-11 (2007).

10. R. Shishoo, Ed., Plasma technologies for textiles, I. Washington, DC: Woodhead Publishing Limited and CRC Press LLC, (2007).

11. H. S. Dachlan, M. Dhofir, and V. Fernanda, "Pengaruh Sudut Keruncingan Dan Diameter Finial Franklin Terhadap Distribusi Medan Listrik Dan Tingkat Tegangan Tembus," $J$. EECCIS, II(1), 1-10 (2008).

12. H. Conrads and M. Schmidt, "Plasma generation and plasma sources," Plasma Sources Sci. Technol., 9(4), 441-454 (2000).

13. R. A. Wolf, Atmospheric Pressure Plasma for Surface Modification, I. Canada: Scrivener Publishing LLC, (2013).
14. F. Fitriani, M. Nur, and F. Arianto, "Karakteristik plasma lucutan berpenghalang dielektrik isian gas Nitrogen," Youngster Phys. J., 6(3), 229-234 (2017).

15. N. V. Bhat, an Netravali, av Gore, mp Sathianarayanan, ga Arolkar, and rr Deshmukh, "Surface modification of cotton fabrics using plasma technology," Text. Res. J., 81(10), 1014-1026 (2011).

16. B. Ghimire, D. P. Subedi, and R. Khanal, "Improvement of wettability and absorbancy of textile using atmospheric pressure dielectric barrier discharge," AIP Adv., 7(8), 2017.

17. A. Zainal Abidin, G. Susanto, and Puspasari, "Sintesis dan Karakterisasi Polimer Superabsorban dari Akrilamida," Kelompok Keahlian Peranc. dan Pengemb. Prod. Tek. Kim., 2-11 (2012).

18. A. M. Shoushtari, A. Haji, and A. Jafari, "Surface Modification of Polypropylene Nonwoven Fabric with Plasma Activation and Grafting," 1 no. October 2010, 410-414 (2015).

19. D. M. De Oliveira, M. O. Hilário Cioffi, K. C. C. De Carvalho Benini, and H. J. Cornelis Voorwald, "Effects of plasma treatment on the sorption properties of coconut fibers," Procedia Eng., 200, 357-364 (2017).

20. Y. Akishev, M. Grushin, V. Karalnik, I. Kochetov, A. Napartovich, and N. Trushkin, "Generation of atmospheric pressure nonthermal plasma by diffusive and constricted discharges in air and nitrogen at the rest and flow," J. Phys. Conf. Ser., 257(012014), 1-12 (2010). 